\title{
A Comparative Study on the Composition of the Clastic and the Parent Rock of the Source Area in the Yanchang Formation in the Longdong Area of the Ordos Basin
}

\author{
He Taping, Yun Yuping \\ Exploration and Development Technology Research Center, Yanchang Petroleum Co., Ltd., Yan'an, China
}

Email address:

710233010@qq.com (He Taping),554539805@qq.com (Yun Yuping)

\section{To cite this article:}

He Taping, Yun Yuping. A Comparative Study on the Composition of the Clastic and the Parent Rock of the Source Area in the Yanchang Formation in the Longdong Area of the Ordos Basin. Earth Sciences. Vol. 10, No. 2, 2021, pp. 64-69. doi: 10.11648/j.earth.20211002.13

Received: April 21, 2021; Accepted: May 7, 2021; Published: May 14, 2021

\begin{abstract}
Based on the data of element geochemistry, electron probe, tectonic attributes, etc., the composition of the clastic and parent rock in the source area was analyzed for the Yanchang Formation in Longdong area. Research shows that the Yanchang Formation includes single crystal quartz, polycrystalline quartz, bicyclic quartz, fragmented quartz, dust-rich turbid quartz, and wavy matte quartz. Different types of quartz come from different parent rocks in different areas of the basin. Feldspar mainly comes from Guanshan pluton, Cuihua mountain, Haiyuan, and Longxi intermediate acid biotite granite in the periphery of the basin. In the Yanchang Formation in the study area, most of the heavy minerals in the sandstone formed by the northeast provenance come from the metamorphic parent rock in the Yinshan area, while the heavy minerals in the sandstone formed by the southwest provenance are formed in the hydrothermal metamorphic parent rock. The content of heavy minerals varies greatly in different depositional stages, and the provenance direction of sandstone in different intervals and the type of parent rock in the source area vary. The cuttings particles have a long transport distance, fine particle size, little cuttings retention, poor stability of rock structure and composition, weak resistance to weathering, and low cuttings content.
\end{abstract}

Keywords: Ordos Basin, Longdong Area, Yanchang Formation, Clastic Component, Parent Rock Component

\section{Introduction}

The study of sedimentary characteristics of lake basins has always been one of the key contents of petroliferous basin research [1-3]. In recent years, with the acceleration of the exploration and development of oil and gas resources and the rapid advancement of science and technology, domestic and foreign research on continental lake basins has entered a new stage [1-4]. The Mesozoic Yanchang Formation in the Ordos Basin contains rare low-permeability and ultra-low-permeability oil reservoirs in the world [5-7]. During the extended period of the Late Triassic, the Longdong area was at the center of the southwest subsidence of the Ordos Lake Basin. This area has a large stratum thickness, strong sedimentary rhythm, complex rock composition, many oil-bearing layers, and abundant reserves. It is the most enriched and most representative area of low-permeability and ultra-low-permeability reservoirs in the basin, and has very broad prospects for exploration and development [8-11].

The storage properties of sandstone are determined by the structure of sandstone, and the structure of sandstone is controlled by material composition [12-14]. The clastic comparison method not only refers to the comparison of the type and content of the clastic composition of the sandstone in the sedimentary basin with the possible parent rock composition at the periphery of the basin, and more importantly, by studying the characteristics of quartz, feldspar and cuttings, restore their provenance direction and parent rock [15]. Facts have proved that the quartz, feldspar and cuttings comparison method is a conventional and effective method.

\section{Comparative Analysis and Provenance Determination of Quartz and Feldspar}

In the statistical analysis of the composition, typomorphic characteristics, and content characteristics of the quartz, 
feldspar and other debris particles in the Yanchang Formation in the study area, it was found that quartz in the Yanchang Formation sandstones can be monocrystalline, polycrystalline, bicyclic quartz, fragmented quartz, dust-rich turbid quartz, and wavy matte quartz, depending on the source direction and the genetic type of the parent rock in the source area.

The common bicyclic quartz in single crystal quartz is most distributed in the basin. They are distributed in the sandstones of the Chang 8 in Well ZH49, Chang $4+5$ in Well G8, and Chang 6 in Well ZH15. The particles on the quartz microscope have an enlarged nucleus and a double-layer structure. The edges of the nucleus have obvious or inconspicuous thin dust edges, and the secondary enlarged edges of quartz have obvious abrasion or clay film. These mainly come from the pre-Palaeozoic sedimentary rocks of the basement of the basin margin and the metamorphic parent rocks of the Precambrian sedimentary rocks in the Qinling orogenic belt; Fractured quartz is the intragranular microcracks of quartz under stress, and these cracks are filled by late silica, mainly from the Qinling orogenic belt in the southern margin of the basin and the thrust belt in the western margin. It has high hydrothermal effect and strong tectonic stress conditions during formation; The morphological characteristics of quartz grains in pyroclastic rocks are spear-shaped and chicken-bone-shaped. They are commonly found in Chang 8 and Chang 6 sandstones in Mubo, Shangliyuan, Huanxian and Heqi areas. It may come from the northwestern margin of the Alxa Group, the volcanic rocks of the Zhartai Group, metatuff, etc.; The dust-rich turbid quartz mainly comes from the Precambrian in the Yinshan area of the northern margin of the basin; The wavy matting quartz is the result of the local intercourse or slippage of the crystal structure of the quartz particles under the action of in-situ stress, which is more common in the northeast delta system. It is speculated that it may come from the precambrian metamorphic rock strata in the Yinshan and Luliang uplift in the northern margin. Polycrystalline quartz is mainly found in the ancient gneiss on the edge of the basin. The crystal grains are mostly in suture-like contact. The crystal grains are similar in size, nearly equiaxed in shape and non-oriented arrangement. It is more common in Chang 8 sandstone in the study area, and it is speculated to come from the gneiss at the base of the Qinling paleo-uplift.

Feldspar is another very important mineral in the sandstone of Yanchang Formation. It has fine grains, well-sorted, high content, generally $20 \%-65 \%$, and is widely distributed. The nature and quantity of feldspar often become the basis for rock classification and naming. Accurately determining the nature of feldspar, distinguishing the types of feldspar, and studying the characteristics of feldspar are particularly important for provenance analysis and diagenesis research. The electron probe component analysis of feldspar is of great significance in provenance research.

According to the electronic probe composition analysis of plagioclase in the study area (Table 1), the chemical composition is mainly intermediate-acid plagioclase. Combined with the distribution of biotite, it is believed that it mainly comes from the Guanshan pluton, Cuihua Mountain, Haiyuan and Longxi mid-acid biotite granite in the periphery of the basin. In addition, some ring-shaped plagioclase is also related to igneous rocks and basic intrusive rocks and metamorphic rocks of Yinshan old strata. In addition, there are more potash feldspars than plagioclase, and the alteration is intense. It mainly comes from the granite and granite gneiss area with violent crustal movement, abundant material sources and dry climate.

Table 1. Analysis table of plagioclase component content in Chang 8 sandstone particles (\%).

\begin{tabular}{|c|c|c|c|c|c|c|c|c|c|}
\hline Region & $\mathrm{SiO}_{2}$ & $\mathrm{TiO}_{2}$ & $\mathbf{A l}_{2} \mathbf{O}_{3}$ & $\mathrm{FeO}$ & MnO & MgO & $\mathrm{CaO}$ & $\mathrm{K}_{2} \mathrm{O}$ & $\mathrm{Na}_{2} \mathrm{O}$ \\
\hline Huachi-Baibao & 66.45 & 0.015 & 22.26 & 0.15 & 0.01 & 0.05 & 0.33 & 0.085 & 11.05 \\
\hline Qingjian-Yan'an & 65.43 & 0.00 & 22.02 & 0.03 & 0.00 & 0.065 & 1.15 & 0.01 & 10.77 \\
\hline Xifeng & 65.81 & 0.033 & 21.99 & 0.11 & 0.023 & 0.048 & 0.87 & 0.008 & 10.67 \\
\hline Jingbian & 67.27 & 0.00 & 21.83 & 0.10 & 0.01 & 0.00 & 0.22 & 0.00 & 11.35 \\
\hline Ningxian & 64.37 & 0.00 & 22.15 & 0.08 & 0.02 & 0.07 & 0.83 & 5.83 & 6.68 \\
\hline Qingyang & 65.15 & 0.01 & 22.54 & 0.14 & 0.006 & 0.09 & 1.27 & 0.234 & 10.98 \\
\hline Tongchuan & 64.91 & 0.00 & 22.04 & 0.14 & 0.00 & 0.14 & 2.28 & 0.27 & 10.07 \\
\hline
\end{tabular}

(electron probe $\mathrm{n}=49$ )

\section{Comparative Analysis and Provenance Determination of Heavy Minerals}

Different types of parent rocks have different mineral compositions, and different heavy mineral combinations will be produced after weathering and transportation damage. Therefore, the content and types of heavy minerals in different areas of the basin and different types of sandstones are also different (Figure 1). The Yanchang Formation in the study area is a multi-source deposit with many types of heavy minerals. According to the weathering stability of heavy minerals, it can be divided into two types: One type is stable heavy minerals, mainly including rutile, zircon, tourmaline, anatase, garnet, ilmenite, magnetite, staurolite, etc. It has strong resistance to weathering and is widely distributed, and its content far away from the parent rock area is relatively high; The other is unstable heavy minerals, mainly including hornblende, pyroxene, andalusite, etc. It has weak resistance to weathering, is not widely distributed, and its content is relatively reduced away from the parent rock area. 


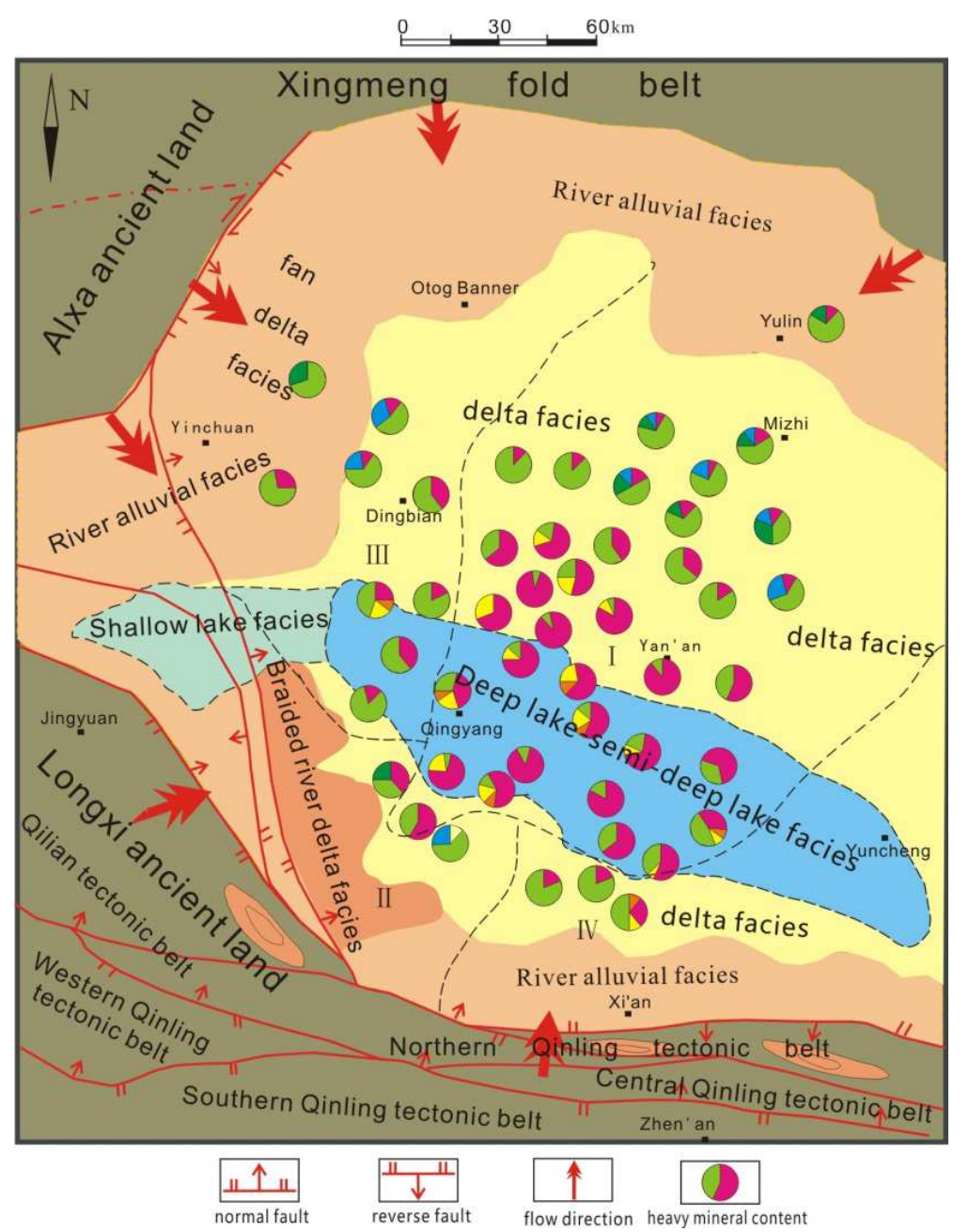

Figure 1. Source and heavy mineral distribution map of Yanchang Formation in the study area.

The change and combination of heavy mineral content in the Yanchang Formation sandstone can reflect the provenance characteristics and changes from two aspects: profile and plane. On the one hand, the types, contents, and combination types of heavy minerals between different zones in the same oil layer group. Take Chang 3 as an example of the characteristics of heavy minerals (Table 2). It can be seen that in the Baibao area of Longdong, the garnet is $22.96 \%$, the tourmaline in Zhenyuan-Maling area is as high as $23.92 \%$, the Baibao tourmaline is $17.83 \%$, and the rutile in the Zhenyuan-Maling area is as high as $5.77 \%$. It shows that in the Baibao delta system formed by the Northeast provenance, there are a large number of metamorphic parent rocks from the Yinshan region's dynamic action zone. However, in the delta system formed by the provenance of the southwestern basin in the Zhenyuan-Maling area, hydrothermal metamorphic parent rocks are the main ones, with strong zoning. Similarly, in the Longdong area, the characteristics of the composition of the heavy mineral content of Chang 8 are also very regional (Table 3). In Zhenyuan, the content of sphene is $4.4 \%$, and the content of garnet in Guchengchuan is based on the source area's parent rock type, weathering material, and the transport paths and deposition sites of heavy minerals carried by it. Therefore, heavy minerals and combinations can trace the direction of the source area [16]. The second aspect is to compare the Chang 3 and Chang 8 oil layer groups in the Huanxian area and the Zhenyuan-Maling area between different oil layer groups in the same area (Table 4). The content of heavy minerals varies greatly, indicating that the provenance direction of sandstone in different intervals and the type of parent rock in the source area have changed. It also shows that at different depositional stages of the Yanchang Formation, the type of parent rock in the denudation zone of the orogenic belt will change with the progress of the erosion zone.

Table 2. Distribution table of heavy mineral content of Chang 3 (\%).

\begin{tabular}{llllll}
\hline Region & Zircon & Rutile & Tourmaline & Garnet & Hard Chlorite \\
\hline Huanxian & 80.15 & 1.63 & 4.92 & 13.30 & 0 \\
Zhenyuan - Maling & 61.11 & 5.77 & 23.92 & 7.46 & 1.75 \\
Baibao & 56.80 & 2.23 & 17.83 & 22.96 & 0.18 \\
\hline
\end{tabular}


Table 3. Statistical table of heavy mineral content in different zones of Chang 8 (\%).

\begin{tabular}{|c|c|c|c|c|c|c|c|c|c|}
\hline Well area & Number of samples & Zircon & rutile & tourmaline & garnet & titanite & Green curtain stone & hard chlorite & White titanium mine \\
\hline Yanwu & 5 & 44.9 & 1.16 & 3.66 & 29.56 & 0.00 & 0.04 & 2.50 & 16.82 \\
\hline Zhenyuan & 24 & 11.73 & 0.98 & 1.28 & 43.43 & 4.40 & 0.00 & 1.44 & 14.32 \\
\hline Zhenyuan North & 39 & 15.29 & 0.50 & 2.39 & 42.07 & 0.01 & 0.00 & 2.75 & 27.58 \\
\hline Xifeng & 1 & 61.50 & 1.00 & 0.00 & 10.00 & 0.00 & 0.00 & 2.00 & 20.00 \\
\hline Qingyang & 83 & 22.93 & 2.11 & 4.09 & 35.03 & 0.00 & 0.02 & 2.84 & 24.89 \\
\hline Banqiao & 19 & 18.46 & 1.02 & 1.95 & 57.07 & 0.00 & 0.00 & 0.66 & 17.58 \\
\hline Guchengchuan & 13 & 20.08 & 3.51 & 4.32 & 44.45 & 0.00 & 0.04 & 6.02 & 21.06 \\
\hline Chenghao & 9 & 36.49 & 1.93 & 4.74 & 24.12 & 0.00 & 0.03 & 2.72 & 23.82 \\
\hline
\end{tabular}

Table 4. Statistical comparison table of heavy mineral content of different oil layer groups in the same area (\%).

\begin{tabular}{|c|c|c|c|c|c|c|}
\hline Well area & Stratum & Zircon & Rutile & Tourmaline & Garnet & Hard Chlorite \\
\hline \multirow{2}{*}{ Huanxian } & Chang 3 & 80.15 & 1.63 & 4.92 & 13.30 & 0 \\
\hline & Chang 8 & 44.9 & 1.16 & 3.66 & 29.56 & 2.50 \\
\hline Zhenyuan - Maling & Chang 3 & 61.11 & 5.77 & 23.92 & 7.46 & 1.75 \\
\hline
\end{tabular}

\section{Comparative Analysis of Cuttings and Determination of Provenance}

The debris in the clastic rock is the only mineral aggregate that maintains the structure of the parent rock. Compared with other clastic particles, there is more evidence of the source rock area. The content of cuttings depends on the structural stability of the source area, the supply of weathering material, and the speed of transportation and deposition. In areas where structures and volcanic activities are frequent, the supply of cuttings is abundant, and the sandstone cuttings with fast deposition rate are retained; At the same time, the content of cuttings is also related to the composition of the parent rock and the stability of the physical and chemical conditions in the process of transporting sediments and diagenesis. The difference in particle transport distance, particle size, composition and structure of various parent rocks, and different stability during sedimentation and diagenesis lead to different cuttings content. The particle transport distance is long, the particle size is fine, the cuttings retention is small, the rock structure and composition stability are poor, the weathering resistance is weak, and the cuttings content is low, otherwise the opposite is true. Therefore, the content of cuttings in different levels of clastic rocks varies greatly.

According to the analysis of regional geological characteristics, the potential parent rock of the Yanchang Formation is composed of two parts: one part is the weathered alluvial deposits of the ancient bedrock in the Yinshan and Qinling orogenic belts, Lvliang, Longxi, Haiyuan, Qianlishan paleo-uplift and orogenic belts, and the other part is The Paleozoic bedrock of the Yanchang period before the edge of the basin. According to the analysis of the Yanchang Formation sandstone in the Longdong area of the basin, the content of cuttings is generally about $5 \%-10 \%$. Among the cuttings types, common igneous rocks include granite, volcanic eruption, tuff and cryptocrystalline rock. Granite cuttings are mainly found in the Chang 8, Chang 4+5 and Chang 9 sandstones in the Xifeng, Zhenyuan, and northeastern peripheral outcrops in the southwestern part of the basin. The volcanic rock fragments include both intermediate-acid eruption rocks, tuff and basic eruption rocks. Basic volcanic rocks are distributed in Chang 8 and Chang $4+5$ in Xifeng, Heshui and Zhenyuan; Metamorphic rocks include quartzite, schist, slate, phyllite and schist, etc. The phyllite is composed of shallow metamorphic rock fragments with scale-like minerals as the main body, and has obvious directional structure, indicating that the parent rock is Paleozoic and the Middle-Upper Proterozoic shallow metamorphic rock series. Quartzite is a regional metamorphic quartzite, which comes from the alteration products of the Zhaertai Group, Baiyun Obo Group, and Alxa Group in the northern margin of the ancient land. The mica quartz schist has a direct genetic relationship with the Proterozoic and Archean metamorphic rocks in the northern margin. Gneiss originates from the lower Proterozoic, Archean and mid-deep metamorphic rock series in the Yinshan and Qinling orogenic belts in the periphery of the basin, and is distributed in a small amount in the Chang 8 braided river delta plain deposits in the southwest direction; The common types of sedimentary rocks are carbonate rock, siltstone and mudstone. Carbonate cuttings are the most important cuttings type in the Yanchang Formation sandstone in the area. Take the Chang 8 oil layer group as an example (Figure 2), and the content is high in Ningxian, Zhenyuan, and Mubo areas, and the content in Xifeng and Tongchuan is relatively low. It is speculated that it mainly originated from the southern Weibei paleo-uplift and the Pingliang ancient land belonging to the Cambrian and Ordovician carbonate platform.

Due to the different provenance directions, the types and content of cuttings are different (Table 5). Chang 8 has high content of igneous rock and metamorphic debris in Baibao and Xifeng areas, $8 \%-14 \%$ and $7 \%-11 \%$, respectively, while in Guchengchuan and Huanxian areas, sedimentary rock debris content is high, about $3.41 \%-5.13 \%$. It shows that the cuttings have a strong zoning and zoning. Similarly, the composition of cuttings in other zones is different due to differences in provenance. Obviously, it is a more effective method to restore the nature of the parent rock and the direction of the provenance by using the type and content of 
cuttings to change.

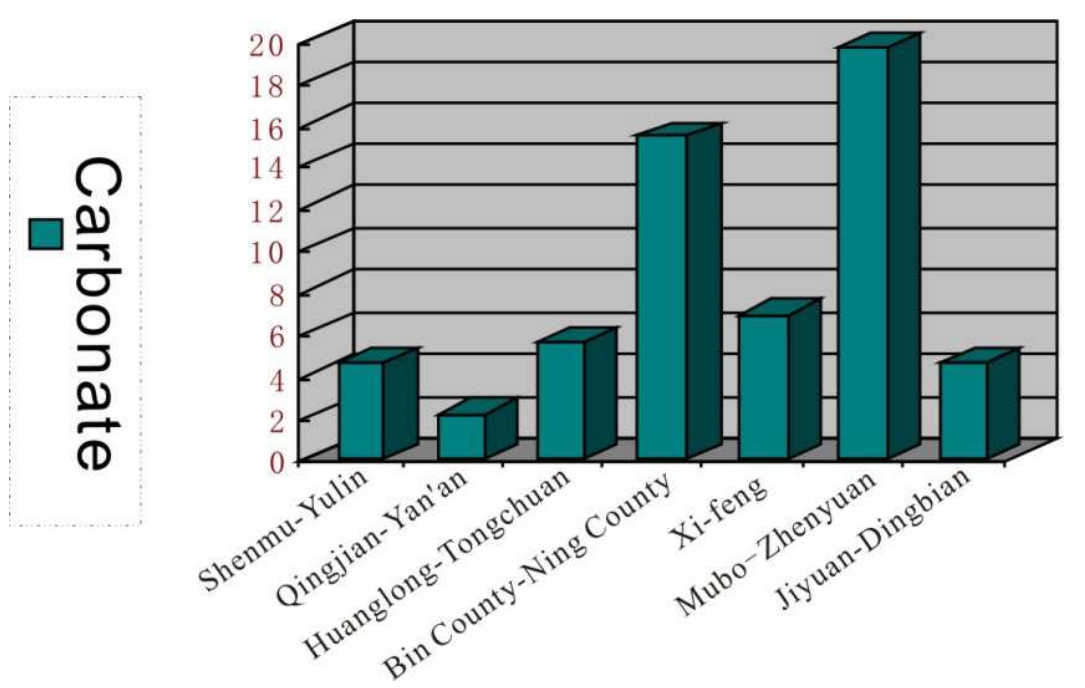

Figure 2. Distribution frequency of carbonate cuttings in Chang 8 sandstone cuttings in different zones.

Table 5. Statistical Table of Clastic Content of Chang 8 Sandstone in Longdong Area (\%).

\begin{tabular}{lllllllll}
\hline \multirow{2}{*}{ Well area } & $\begin{array}{l}\text { Number of } \\
\text { wells }\end{array}$ & $\begin{array}{l}\text { Number of } \\
\text { samples }\end{array}$ & Quartz & Feldspar & Cuttings & & Mica and \\
\cline { 6 - 9 } Chlorite
\end{tabular}

\section{Conclusion}

(1) Different types of quartz in the Yanchang Formation in the study area come from different parent rocks in different areas on the edge of the basin. Feldspar mainly comes from Guanshan pluton, Cuihua mountain, Haiyuan and Longxi intermediate acid biotite granite in the periphery of the basin.

(2) In the Baibao delta system formed by the sandstones of the Yanchang Formation in the study area, most of the heavy minerals come from the metamorphic parent rocks in the dynamic action area of the Yinshan region, while the southwestern source heavy minerals are formed in the hydrothermal metamorphic parent rocks. The content of heavy minerals varies greatly in different depositional stages, and the provenance direction of sandstone in different intervals and the type of parent rock in the source area vary.

(3) The content of cuttings is not only affected by the structural stability of the source area, the supply of weathered material, and the speed of transport and deposition, but also the composition of the parent rock and the stability of the resistance to weathering during the physical and chemical conditions during transport and sedimentation and diagenesis. The particle transport distance is long, the particle size is fine, the cuttings retention is small, the rock structure and composition stability are poor, the weathering resistance is weak, and the cuttings content is low, otherwise the opposite is true. Therefore, the content of cuttings in different levels of clastic rocks varies greatly.

\section{References}

[1] Cao Yingchang, Jin Jiehua, Liu Haining, et al. Deep-water gravity flow deposits in a lacustrine rift basin and their oil and gas geological significance in eastern China[J]. Petroleum Exploration and Development, 2021, 48 (2): 247-257.

[2] Yuan Xuanjun, Zhou Hongying, Zhang Zhijie, et al. Depositional features and growth pattern of large shallow-water deltas in depression basin. Lithologic Reservoirs, 2021, 33 (1): 1-11.

[3] Fan Leyuan, Wu Jiapeng, Diao Wan, et al. Sedimentary characteristics of the shallow water delta in rifted lacustrine basin: A case study in the Aradeiba Formation, Unity Sag, Muglad Basin. Earth Science Frontiers, 2021, 28 (01): 155-166.

[4] Wang Jiahao, Wang Hua, Xiao Dunqing, et al. Differentiation between hyperpycnal flow deposition and slump-induced gravity flow deposition in terrestrial rifted lacustrine basin [J]. Acta Pctrolci Sinica, 2020, 41 (04): 392-402, 411. 
[5] Gao Yi, Lin Lifei, Yin Shuai, Hu Guoxiang, et al. Characteristics of in situ stress of tight oil reservoirs and its influence on petrophysical properties: A case study of Upper Triassic Yanchang Formation in Ordos Basin [J]. Petroleum Geology\&Experiment, 2021, 43 (02): 250-258.

[6] Liu Jiangbin, Wu Xiaobin, Li Dan, et al. The Main Controlling Factors Of Tight Oil Reservoir Forma-Tion Of The Chang6 Member Of Triassic Yanchang Formation In Shuanglong Area, Ordos Basin[J]. Mineralogy And Petrology, 2021, 41 (01): 116-127.

[7] Zhong Hongli, Zhang Fengqi, Zhao Zhenyu, et al. Micro-scale pore-throat distributions in tight sandstone reservoirs and its constrain to movable Fluid [J]. PETROLEUM GEOLOGY \& EXPERIMENT, 2021, 43 (01): 77-85.

[8] Liu Hanlin, Qiu Zhen, Xu Liming, et al. Distribution of shallow water delta sand bodies and the genesis of thick layer sand bodies of the Triassic Yanchang Formation, Longdong Area, Ordos Basin [J]. Petroleum Exploration and Development, 2021, 48 (1): 106-117.

[9] Zhang Xiaohui, Feng Shunyan, Liang Xiaowei, et al. Sedimentary microlacies identification and inferred evolution of the Chang 7 Member of Yanchang Formation in the Longdong area, Ordos basin. Acta Geologica Sinica, 2020, 94 (03): 957-967.

[10] Ma Yao, Shi Tao, Crown Man, et al. Sandbody structural characteristics and genetic model of Chang $8_{2}$ in Longdong area. Journal of Northwest University (Natural Science Edition), 2019, 49 (05): 765-771.
[11] Qiu Yajie, Li Baiqiang, Li Yang, et al. Sedimentary microfacies characteristics of Chant 9 reservoir in Huaqin? area, Ordos Basin [J]. Journal of Xi'an Shiyou University (Natural Science Edition), 2015, 30 (04): 1-5+7.

[12] Li Yijia, Ruan Zhuang, Liu Shuai, et al. Provenance and Tectonic Setting of Chang 10-Chang 8 Member in the Southern Ordos Basin [J]. Geoscience, 2020, 34 (4): 784-799.

[13] Fan Mengmeng, Bu Jun, Li Wenhou,. Early provenance and sedimentary environment characteristics of the Yanchang Formation in the southeast of Ordos Basin [J]. Chinese Journal of Geology, 2020, 55 (03): 782-794.

[14] Liu Shuai, Ruan Zhuang, Yang Zhihui, et al. Provenance evolution of southern margin of Ordos Basin during the Middle-Later Triassic and its geological implication[J]. Journal Of Palaeogeography (Chinese Edition), 2019, 21 (06): 939-958.

[15] Feng Yujing, Long Hao, Huang Yinzhou, et al. Luminescence dating of Holocene lacustrine sediments from the southeastern $\mathrm{Mu}$ Us sandy land: Comparison of quartz OSL and K-feldspar pIRIR $_{150}$ ages [J]. J. Lake Sci., 2015, 27 (03): 535-547.

[16] Pan Jie, Liu Zhongqun, Po Renhai, et al. Provenance Direction and Sedimentary Facies of Chang 7-Chang 8 Members in Yanchang Formation of Jinghe Oilfield, Southwest Margin of Ordos Basin [J]. ACTA SEDIMENTOLOGICA STNTCA, 2017, 35 (01): 124-138. 